\title{
Superação In Vitro da dormência de embriões de Pereira oriundos de hibridações
}

\author{
Cláudia Simone Madruga Lima*1, Gabriela Gerhardt da Rosa ${ }^{2}$, Zeni Fonseca Pinto Tomaz ${ }^{3}$,
} Marcia Wullf Schuch ${ }^{3}$ e Andrea De Rossi Rufato ${ }^{4}$

${ }^{1}$ Universidade Federal da Fronteira Sul, Laranjeiras do Sul, Paraná, Brasil. E-mail: claudia.lima@uff.edu.br

${ }^{2}$ Universidade Federal de Pelotas, Departamento de Botânica, Pelotas, Rio Grande do Sul, Brasil. E-mail: birela89@gmail.com

${ }^{3}$ Universidade Federal de Pelotas, Departamento de Fitotecnia, Pelotas, Rio Grande do Sul, Brasil.

E-mail: zfptomaz@yahoo.com.br; marciaws@ufpel.tche.br

${ }^{4}$ Embrapa Uva e Vinho, Estaçáo Experimental de Fruticultura de Clima Temperado, Vacaria, Rio Grande do Sul, Brasil.

E-mail: andrea.rufato@embrapa.br

* Autora para correpondência: claudia.lima@uffs.edu.br

ISSN 2448-0479

Resumo - Objetivou-se verificar a influência de diferentes meios de cultura na superação in vitro da dormência de embrióes oriundos de hibridação. Embriōes foram retirados de sementes oriundas de hibridaçôes controladas e inoculados nos meios de cultivo: MS; $\mathrm{MS} / 2$; QL e QL/2, mantidos em sala de crescimento a $25 \pm 2^{\circ} \mathrm{C}$ e fotoperíodo de 16 horas. O delineamento experimental foi inteiramente casualizado com dois fatores analisados (hibradaçóes e meios de cultura), em esquema fatorial $3 \mathrm{X}$, sendo que cada repetiçâo constituiu-se de um frasco, com cinco embrióes cada. Aos 60 dias de cultivo, o material foi avaliado. Os dados foram submetidos à análise de variância e as médias dos tratamentos comparadas estatisticamente pelo teste de Tuckey $(\alpha=0,05)$. Houve interaçáo entre os fatores (meios de cultura e hibridaçóes) para todas as variáveis respostas analisadas. A maior percentagem de germinaçấo $(53,49 \%)$, foi obtida na associaçấo do meio de cultura QL/2 com embriōes oriundos do tratamento 2. O maior número e comprimento de brotaçôes foi verificado na combinação de embriôes do tratamento 1 cultivadas em meio QL e o maior crescimento radicular foi observado no cultivo realizado em meio MS com os embrióes oriundos dos tratamentos 1 e 2 . O meio QL/2 proporcionou o maior número de embrióes de porta-enxertos de pereira germinados. Entretanto o meio QL completo é o mais adequado para multiplicação.

Palavras-Chave - Porta-enxerto. Polinização aberta. Packham's Triumph. In vitro. Melhoramento vegetal.
Abstract - This study aimed to investigate the influence of different culture media on the in vitro overcoming dormancy of embryos derived from hybridization. Embryos were removed from seeds from controlled hybridizations and inoculated in culture media: MS; MS /2; QL and QL /2, maintained in a growth room at $25 \pm 2^{\circ} \mathrm{C}$ and $16 \mathrm{~h}$ of photoperiod. The experimental design was completely randomized with two factors analyzed (hybridizations and culture media) in a factorial $3 \times 4$, each repetition consisted of a bottle with five embryos each. After 60 days of culture, the material was analyzed. The data were submitted to analysis of variance and treatment means compared statistically by the Tukey test $(\alpha=0.05)$. There was interaction between the factors (culture media and hybridizations) for all variables. The highest percentage of germination $(53.49 \%)$ was obtained from the association of culture medium QL / 2 with embryos from the 2 treatment. The greater number and length of sprouts was observed in the combination treatment of embryos cultured in medium 1 QL and root growth was observed in the cultivation carried out on MS medium with the embryos from treatments 1 and 2. The medium QL / 2 provided the greatest number of germinated pear rootstocks embryos. However, QL medium is suitable is the most suitable for multiplication.

Keywords - Rootstocks; Open cross; Packham's Triumph; In Vitro; Breeding. 
Recebido em: 07 de maio de 2016

Aprovado em: 08 de agosto de 2016

\section{INTRODUÇÃO}

A cultura da pereira na Regiāo Sul do Brasil é uma excelente alternativa para a diversificação da fruticultura de clima temperado, uma vez que é uma das frutas com maior volume de importaçôs. Contudo, vários problemas técnicos e ecofisiológicos vêm limitando o cultivo econômico da pereira, destacando se a falta de porta enxertos adequados (PIO et al., 2007; PASA et al., 2012).

A busca por novos genótipos de pereira que apresentem boa compatibilidade de enxertia e adaptação às condiçốes edafoclimaticas do Sul do país são contínuas, e o uso de técnicas do melhoramento genético como a hibridação e a micropropagação são ferramentas importantes para obtençáo de porta enxertos para pereira.

A baixa porcentagem e desuniformidade de germinação, principalmente nos cruzamentos em que são produzidas sementes em pequeno número, constituem um dos fatores limitantes à obtenção de materiais híbridos (NEVES et al., 2001). Em plantas como as pereiras que apresentam um longo intervalo de tempo a partir do cruzamento até a germinação, torna-se mais difícil e longos os programas de melhoramento genético para esta espécie, que podem ter seu período juvenil encurtado com técnicas de micropropagação (BRUCKNER, 2008).

Com o desenvolvimento de técnicas de cultivo in vitro, tornou-se possível, entre outras, obter plantas viáveis em menos tempo. Isto pode ser obtido mediante o isolamento do embrião e seu cultivo asséptico em meios de cultura adequados que permitam a superação da dormência, o desenvolvimento embrionário e a germinação (DANTAS et al., 2002).

Entre os aspectos importantes na cultura de embriôes estão a definição do meio de cultura, condiçôes de luminosidade e temperatura, condiçôes da planta matriz, a qualidade dos explantes, entre outros (MINARDI et al., 2011). Conforme Costa e Aloufa (2007) um dos aspectos mais importante da cultura de embriōes, é a determinação do meio de cultura, pois este é que sustentará o crescimento dos embrióes. Os nutrientes requeridos variam dependendo da idade do explante (BURUN; POYRAZOGLU, 2002). De acordo com Hu e Ferreira (1998), embri- óes excisados no estádio maduro ou próximo a este, são quase autotróficos, dispensando a utilizaçáo de reguladores vegetais.

Diversas formulaçôes de meio de cultura têm sido empregadas na cultura de embrióes, as quais diferem entre si basicamente em relação à concentração dos sais (REZENDE et al., 2008). Segundo Jesus et al. (2010), o meio de cultura MS (MURASHIGE; SKOOG, 1962) é conhecido por apresentar elevado conteúdo de sais. Já o meio proposto por Leblay et al. (1991) possui o dobro da concentração de vitaminas na sua composição, quando comparado com o meio de cultura MS. Reis et. al. (2008) analisando o desenvolvimento in vitro de embriôes de Melissa officinalis L., relacionando-o com a reduçấo da concentraçâoo dos sais do meio MS, observaram o uma correlação direta com a diminuição da concentração e o melhor desenvolvimento das plântulas.

Diante do exposto, o objetivo neste trabalho foi verificar a influência de diferentes meios de cultura na superação in vitro da dormência de embriōes oriundos de hibridaçáo de porta-enxertos de pereira.

\section{MATERIAL E MÉTODOS}

Frutos de pereira oriundos de hibridações controladas foram colhidos maduros, mantendo-se a identificação das polinizações dirigidas. Esta etapa foi realizada em pomar comercial no município de Vacaria/RS, Brasil. Os cruzamentos foram definidos como: T1- Polinização aberta; T2- autopolinização de Packham's Triumph e T3- Packham's Triumph X Clapps Favorite.

A etapa laboratorial foi conduzida no Laboratório de Micropropagação de Plantas Frutíferas, FAEM/UFPel. As sementes oriundas das hibridações foram removidas mediante corte transversal do fruto, sendo submetidos a uma desinfestação em álcool $70 \%$ por 10 segundos e, em hipoclorito de sódio a $2,5 \%$, adicionado de 2 gotas de Tween 20, durante 10 minutos, seguidas de três lavagens com água esterilizada autoclavada.

Os embriōes foram então retirados das sementes e inoculados em frasco de vidro, contendo $30 \mathrm{~mL}$ dos seguintes meios: 1) MS; 2) MS/2; 3) QL (Quiorin; Lepoivre 1977) modificado por Leblay et al. (1991) e 4) QL/2, com a metade dos sais. Os meios foram acrescidos de sacarose $\left(30 \mathrm{gL}^{-1}\right)$, ágar $\left(6 \mathrm{gL}^{-1}\right)$ e suplementado com os seguintes fitorreguladores: ácido indol acético (1 $\left.\mathrm{mL} \mathrm{L}^{-1} \mathrm{AIB}\right)$, 6-benzilaminopurina (5 
$\left.\mathrm{ml} \mathrm{L}^{-1} \mathrm{BAP}\right)$. Para as vitaminas, adicionadas no meio Leblay, as quantidades utilizadas foram de $10 \mathrm{~mL} \mathrm{~L}^{-1}$ para tiamina, ácido nicoticinico e piridoxina, já para glicina utilizou-se $20 \mathrm{~mL} \mathrm{~L}^{-1}$. Após a inoculação, as sementes foram mantidas em sala de crescimento a $25 \pm 2^{\circ} \mathrm{C}$, no escuro, por um período de sete dias. Depois desse período, o material foi transferido para luz, fotoperíodo de 16 horas e densidade de fluxo de fótons de $27 \mu \mathrm{mol} \mathrm{m}{ }^{-2} \mathrm{~s}^{-1}$.

Os tratamentos constituíram-se das três populações de hibridações (T1, T2 e T3) e quatro meios de cultura (MS, MS/2, L, L/2), num fatorial $3 \times 4$, totalizando doze tratamentos. O delineamento experimental utilizado foi inteiramente casualizado com quatro repetiçóes por tratamento, sendo que cada repetiçấo constituiu-se de um frasco, com cinco embriōes cada. Aos 60 dias de cultivo, o material foi avaliado quanto à índice de velocidade de emergência, percentagem (\%) de germinação, número e comprimento $(\mathrm{cm})$ de brotações, número e comprimento $(\mathrm{cm})$ das raízes e percentual (\%) de calos. Os dados foram submetidos à análise de variância e as médias dos tratamentos comparadas estatisticamente pelo teste de Tuckey $(\alpha=0,05)$, por meio do uso do programa estatístico Winstat (MACHADO; CONCEIÇÃO, 2002). Os dados representados em porcentagem foram transformados em arco seno da raiz quadrada de $\mathrm{x} / 100$, em que $\mathrm{x}$ é o percentual obtido.

\section{RESULTADOS E DISCUSSÁO}

Houve interação entre os fatores (meios de cultura e hibridaçôes) para todas as variáveis respostas analisadas. Considerando-se o fator meio de cultura, a maior percentagem de germinaçáo foi obtida na associação de meio de cultura L/2 (LEBLAY et al., 1991) para todos os tratamentos (Tabela 1). Porém para os embrióes submetidos ao meio L completo, observou-se o necrosamento de alguns embriōes.

De acordo com Reis et al. (2008) e Hu e Ferreira (1998), uma maior concentração de sais no meio de cultura pode interferir no potencial osmótico e, conseqüentemente, na disponibilidade de água para o processo de embebição da semente e na germinação, pois a adiçáo de componentes ao meio de cultura, especialmente macronutrientes e fontes de carbono, representam decréscimo no potencial osmótico do meio. Isso explica os resultados encontrados, pois o meio $L / 2$ possui a metade da concentração de sais.
Tabela 1 - Percentagem de germinação e índice de velocidade de emergência (IVE) de embrióes de pereira, oriundos de diferentes hibridaçôes controladas e cultivados em meio de cultura MS, MS/2, L, L/2. Pelotas/FAEM-UFPel, 2012.

\begin{tabular}{|c|c|c|c|c|}
\hline \multirow{2}{*}{$\begin{array}{l}\text { Variável } \\
\text { resposta }\end{array}$} & \multirow{2}{*}{$\begin{array}{c}\text { Meio de } \\
\text { cultura }\end{array}$} & \multicolumn{3}{|c|}{ Hibridaçóes - Tratamentos } \\
\hline & & T1 & T2 & T3 \\
\hline \multirow{4}{*}{$\begin{array}{c}\text { Germinação } \\
(\%)\end{array}$} & MS & $39,02 \mathrm{cA}$ & $39,10 \mathrm{cA}$ & $39,00 \mathrm{cA}$ \\
\hline & $\mathrm{MS} / 2$ & $39,00 \mathrm{cA}$ & $39,29 \mathrm{cA}$ & $38,34 \mathrm{~dB}$ \\
\hline & $\mathrm{L}$ & $40,33 \mathrm{bB}$ & $42,34 \mathrm{bA}$ & $40,22 \mathrm{bB}$ \\
\hline & $\mathrm{L} / 2$ & $49,34 \mathrm{aB}$ & 53,49 aA & $47,39 \mathrm{aC}$ \\
\hline \multicolumn{2}{|c|}{$\mathrm{CV}(\%)$} & \multicolumn{3}{|c|}{6,45} \\
\hline \multirow{4}{*}{ IVE } & MS & $6,45 \mathrm{bB}$ & $7,32 \mathrm{bA}$ & $7,67 \mathrm{cA}$ \\
\hline & $\mathrm{MS} / 2$ & $6,97 \mathrm{bC}$ & 8,00 aA & $7,88 \mathrm{cB}$ \\
\hline & $\mathrm{L}$ & $6,00 \mathrm{cC}$ & $7,19 \mathrm{bB}$ & $8,00 \mathrm{bA}$ \\
\hline & $\mathrm{L} / 2$ & $7,13 \mathrm{aB}$ & $7,99 \mathrm{aB}$ & $8,89 \mathrm{aA}$ \\
\hline \multicolumn{2}{|c|}{ CV (\%) } & & 9,33 & \\
\hline
\end{tabular}

${ }^{*}$ Médias seguidas por letras iguais minúsculas na coluna e maiúsculas na linha não diferem entre si pelo teste de Tukey $(\mathrm{p} \leq 0,05)$. ${ }^{* *}$ Hibridaçôes Tratamentos: T1- Polinização aberta; T2- autopolinizaçăo de Packham's Triumph e T3- Packham's Triumph X Clapps Favorite.

Pérez-Hernández e Grajal-Martín (2011), estudando a porcentagem de germinaçáo de híbridos de manga, cultivados em diferentes composiçóes de meio de cultivo, obtiveram eficiência acima de $80 \%$ na germinação, para embriōes cultivados em meio MS, o mesmo foi observado por Reis et al., (2012) com híbridos de pessegueiro. Entretanto Arbeloa et al., (2009) em teste para a porcentagem de germinação in vitro de genótipos da ameixeira 'Mirabolano', apresentou valores acima de 90\% quando utilizou o meio C2d, além disso, Reis et al., (2008) e Soares et al., (2011), observaram que quando embrióes foram postos em meio MS com redução da concentração dos sais e vitaminas, a percentagem de germinação foi sempre maior, quando comparado aos embriôes postos em MS completo. Desta forma, podemos constatar que os resultados obtidos por esses autores corroboram com os encontrados neste trabalho onde, quando trabalhou-se com teores de sais reduzidos, a germinação dos embriōes foi igual ou superior (meio $L / 2)$.

Já para o índice de velocidade de emergência o maior percentual ocorreu para embrióes oriundos do T3 (Packham's Triumph X Clapps Favorite) associado ao meio de cultura QL/2. Segundo Neves et al. (2001), os embrióes variam em tamanho e forma em função da espécie e variedade, existindo efeito do genótipo no índice de velocidade de emergência e germinação das plântulas, conforme observado neste trabalho. Reis et al. (2008) ao testar a influência do meio de cultura na germinação de sementes de Melissa officinalis, in vitro, observou que o maior índice de 
velocidade de emergência ocorreu para o tratamento com meio MS/4, e concluiu que isso ocorre, devido a presença de maior concentraçáo de sais no meio de cultura, a qual interfere no potencial osmótico dos tecidos dos embriōes, e consequentemente, na disponibilidade de água para o processo de germinação.

Em relação ao número e comprimento de brotações a maior formação foi verificada na combinaçâo de embriōes oriundos de polinização aberta (tratamento 1) cultivadas em meio L. (Tabela 2). De acordo com Dantas et al. (2002) pequenas variações na quantidade de vitaminas e hormônios podem alterar a neoformaçáo de brotos, principalmente para culturas com dificuldades na superaçáo da dormência como macieira e pereira.

Tabela 2 - Número e comprimento de brotaçôes de embriôes de pereira, oriundos de diferentes hibridaçóes controladas e cultivados em meio de cultura MS, MS/2, L, L/2. Pelotas/FAEM-UFPel, 2012.

\begin{tabular}{|c|c|c|c|c|}
\hline \multirow{2}{*}{$\begin{array}{l}\text { Variável } \\
\text { resposta }\end{array}$} & \multirow{2}{*}{$\begin{array}{l}\text { Meio de } \\
\text { cultura }\end{array}$} & \multicolumn{3}{|c|}{ Hibridaçóes - Tratamentos } \\
\hline & & T1 & T2 & T3 \\
\hline \multirow{4}{*}{$\begin{array}{l}\text { Número de } \\
\text { Brotaçôes }\end{array}$} & MS & $1,43 \mathrm{dA}$ & $1,32 \mathrm{cB}$ & $1,29 \mathrm{~dB}$ \\
\hline & $\mathrm{MS} / 2$ & $2,76 \mathrm{cA}$ & $2,45 \mathrm{bB}$ & $2,19 \mathrm{cC}$ \\
\hline & $\mathrm{L}$ & $3,19 \mathrm{aA}$ & $2,98 \mathrm{aB}$ & $2,96 \mathrm{aB}$ \\
\hline & $\mathrm{L} / 2$ & $2,97 \mathrm{bA}$ & $2,37 \mathrm{bB}$ & $2,38 \mathrm{bB}$ \\
\hline \multicolumn{2}{|c|}{$\mathrm{CV}(\%)$} & \multicolumn{3}{|c|}{7,55} \\
\hline \multirow{4}{*}{$\begin{array}{c}\text { Comprimento } \\
\text { das Brotaçóes } \\
(\mathrm{cm})\end{array}$} & MS & $2,19 \mathrm{dA}$ & $2,00 \mathrm{cB}$ & $1,98 \mathrm{~dB}$ \\
\hline & $\mathrm{MS} / 2$ & $3,12 \mathrm{cA}$ & $2,98 \mathrm{bB}$ & $2,12 \mathrm{cC}$ \\
\hline & $\mathrm{L}$ & $4,23 \mathrm{aA}$ & $3,98 \mathrm{aB}$ & $3,23 \mathrm{aB}$ \\
\hline & $\mathrm{L} / 2$ & $3,29 \mathrm{bA}$ & $3,15 \mathrm{bB}$ & $3,00 \mathrm{bC}$ \\
\hline \multicolumn{2}{|c|}{$\mathrm{CV}(\%)$} & \multicolumn{3}{|c|}{9,34} \\
\hline
\end{tabular}

*Médias seguidas por letras iguais minúsculas na coluna e maiúsculas na linha não diferem entre si pelo teste de Tukey $(\mathrm{p} \leq 0,05)$. ${ }^{* *}$ Hibridaçōes Tratamentos: T1- Polinização aberta; T2- autopolinizaçăo de Packham's Triumph e T3- Packham's Triumph X Clapps Favorite.

De acordo com Soares Filho et al. (2002), o comportamento dos embriōes embora inerente a cada espécie ou cultivar, pode ser influenciado por fatores do meio e ambientais, a exemplo os parentais masculinos envolvidos na polinização que influenciam no crescimento e desenvolvimento do embriáo no presente estudo.

O maior crescimento radicular foi observado no cultivo realizado em meio MS com os embrióes oriundos dos tratamentos 1 e 2 . Entretanto, o número e comprimento de raízes obtidas nestes tratamentos não possibilitam a projeção de aclimatização de plantas, pois os valores são baixos e as raízes são frágeis. Medeiros et al. (2006) em trabalho realizado com Notacactus magnificus concluiu que o maior número de raízes foi obtido em embriōes cultivados em meio MS completo. Reis et al. (2012) em estudo com a germinação de embriōes de pessegueiro, perceberam que quando utilizado o meio MS completo, obtiveram maior número e comprimento de raízes $(7,96$ e $4,01 \mathrm{~cm}$ respectivamente). Soares et al. (2011) ressalta que o aumento do número e do tamanho das raízes pode estar relacionado com o aumento da absorção dos nutrientes.

Tabela 3 - Número e comprimento das raízes e percentual de calo de embrióes de pereira, oriundos de diferentes hibridaçóes controladas e cultivados em meio de cultura MS, MS/2, L, L/2. Pelotas/FAEM-UFPel, 2012.

\begin{tabular}{|c|c|c|c|c|}
\hline \multirow{2}{*}{$\begin{array}{l}\text { Variável } \\
\text { resposta }\end{array}$} & \multirow{2}{*}{$\begin{array}{l}\text { Meio de } \\
\text { cultura }\end{array}$} & \multicolumn{3}{|c|}{ Hibridaçóes - Tratamentos } \\
\hline & & T1 & T2 & T3 \\
\hline \multirow{4}{*}{$\begin{array}{l}\text { Número de } \\
\text { raízes }\end{array}$} & MS & $3,10 \mathrm{aA}$ & $3,09 \mathrm{aA}$ & $2,29 \mathrm{aB}$ \\
\hline & $\mathrm{MS} / 2$ & $2,98 \mathrm{bA}$ & $2,64 \mathrm{bB}$ & $2,17 \mathrm{bC}$ \\
\hline & $\mathrm{L}$ & $2,76 \mathrm{cA}$ & $2,28 \mathrm{cB}$ & $2,00 \mathrm{cC}$ \\
\hline & $\mathrm{L} / 2$ & $2,16 \mathrm{dA}$ & $1,98 \mathrm{dC}$ & $1,50 \mathrm{~dB}$ \\
\hline \multicolumn{2}{|l|}{ CV $(\%)$} & \multicolumn{3}{|c|}{8,26} \\
\hline \multirow{4}{*}{$\begin{array}{l}\text { Comprimento } \\
\text { das raízes }(\mathrm{cm})\end{array}$} & MS & $2,59 \mathrm{aB}$ & $2,79 \mathrm{aA}$ & $2,49 \mathrm{aB}$ \\
\hline & $\mathrm{MS} / 2$ & $2,47 \mathrm{bA}$ & $2,57 \mathrm{bA}$ & $2,39 \mathrm{aB}$ \\
\hline & $\mathrm{L}$ & $2,00 \mathrm{cB}$ & $2,48 \mathrm{cA}$ & $1,99 \mathrm{bB}$ \\
\hline & $\mathrm{L} / 2$ & $2,00 \mathrm{cA}$ & $2,00 \mathrm{dA}$ & $1,89 \mathrm{bB}$ \\
\hline \multicolumn{2}{|l|}{ CV $(\%)$} & \multicolumn{3}{|c|}{6,35} \\
\hline \multirow{4}{*}{ Calo (\%) } & MS & $3,44 \mathrm{bB}$ & $3,55 \mathrm{bB}$ & $3,90 \mathrm{dA}$ \\
\hline & $\mathrm{MS} / 2$ & $3,00 \mathrm{cB}$ & $3,46 \mathrm{bA}$ & $3,73 \mathrm{cA}$ \\
\hline & $\mathrm{L}$ & $4,35 \mathrm{aC}$ & $4,66 \mathrm{aB}$ & $5,32 \mathrm{bA}$ \\
\hline & $\mathrm{L} / 2$ & $4,88 \mathrm{aB}$ & $4,99 \mathrm{aA}$ & $5,00 \mathrm{aA}$ \\
\hline $\mathrm{CV}(\%)$ & & & 8,34 & \\
\hline
\end{tabular}

${ }^{*}$ Médias seguidas por letras iguais minúsculas na coluna e maiúsculas na linha não diferem entre si pelo teste de Tukey $(\mathrm{p} \leq 0,05)$. ${ }^{* *}$ Hibridaçóes Tratamentos: T1- Polinização aberta; T2- autopolinização de Packham's Triumph e T3- Packham's Triumph X Clapps Favorite.

Para que ocorra a formação das raízes, além da disponibilidade de nutrientes é necessária a presença do fitohormonio auxina nos tecidos das plantas, este também é utilizado na cultura in vitro, muitas vezes, altas concentrações deste podem levar a formação de calos (RADMANN et al., 2002). Observou-se que a maior percentagem de formaçáo de calos, neste trabalho, ocorreu quando os embrióes foram inoculados em meio QL/2, principalmente em combinação com o tratamento 3 (5\%). Torres e Caldas (1990) ressaltam que os calos são massas de células desorganizadas, que se multiplicam desordenadamente podendo se diferenciar em tecidos ou órgáos e possuem a capacidade de responderem as injurias, que podem ser químicas ou físicas.

\section{CONCLUSÓES}

Para obtenção de maior número de embriôes de porta-enxertos germinados, o meio $\mathrm{L} / 2$ é o indicado. 
Entretanto para multiplicação de embriōes oriundos de hibridaçóes o meio L completo é adequado.

\section{REFERÊNCIAS}

ARBELOA, A. et al. In Vitro Culture of 'Myrobalan' (Prunus cerasifera Ehrh.) Embryos. Hortscience, v.1, n.44, p.672-1.674, 2009.

BRUCKNER, C.H. Fundamentos do melhoramento de fruteiras. Viçosa: UFV, 2009.

BURUN, B.; POYRAZOGLU, E. Ç. Embryo culture in Barley (Hordeum vulgare L.). Turkish Journal of Biology, Ankara, v. 8, n.26, p.175-182, 2002.

COSTA, N.M.S.; ALOUFA, M.A.I. Desenvolvimento in vitro de embrióes zigóticos de tamareira. Revista Ciências Agronômicas, Fortaleza, v.38, n. 3, p.276-279, 2007.

DANTAS, A.C.M. et al. Superação in vitro da dormência de embrióes do porta-enxerto de macieira M9 (Malus pumilla Mill.). Revista Brasileira Fruticultura, Jaboticabal, v.24, n.1, p.10-14, 2002.

HU, C.Y.; FERREIRA, A.G. Cultura de tecidos e transformaçáo genética de plantas: Cultura de embrióes. Brasília: EMBRAPA, 1998.

JESUS, A.M.S. et. al. Desenvolvimento in vitro de brotaçóes de cafeeiro em diferentes meios de cultura e reguladores de crescimento de planta. Scientia Agraria, Curitiba, v.11, n.6, p.431-436, 2010.

LEBLAY, C. et al. Adventitious shoot regeneration from in vitro leaves of several pear cultivars (Pyrus communis L.). Plant Cell, tissue and organ culture, v.25, n.2. p.99-105, 1991.

MACHADO, A.A.; CONCEIÇÃO, A.R. Sistema de análise estatística para Windows. WinStat. Versão 2.0. Pelotas: UFPel, 2003.

MEDEIROS, L.A. et al. In vitro propagation of Notocactus magnificus. Plant Cell, Tissue and Organ Culture, v.84, n.2, p.165-169, 2006.

MINARDI, B.D. et al. Cultivo in vitro de embriōes zigóticos de Butia eriospatha (Mart. ex Drude) Becc. INSULA Revista de Botânica, Florianopolis, v.40, p.70-81, 2011.

MURASHIGE, T.; SKOOG, F.A.A. Revised medium for rapid growth and bioassays with tobacco tissue cultures. Physiologia Plantarum, Wojtaszek, v.15, n. 3, p.473497, 1962.

NEVES, T.S. et al. Resgate in vitro de embrióes em ge- nótipos diplóides de bananeira. Pesquisa Agropecuária Brasileira, Brasília, v.36, n.2, p.285-290, 2001.

PASA, M.S. et al. Desenvolvimento, produtividade e qualidade de peras sobre porta-enxertos de marmeleiro e pyrus calleryana. Revista Brasileira de Fruticultura, Jaboticabal, v. 34, n. 3, p. 873-880, 2012.

PÉREZ-HERNÁNDEZ, J.B.; GRAJAL-MARTÍN, M.J. In vitro culture of immature zygotic mango embryos and plantlet development. Hortscience, v.46, n.1, p.528$1.532,2011$

PIO, R. et al. Cultivares de pereira em diferentes porta -enxertos de marmeleiros na regiáo sub-tropical. Revista UDO Agrícola, v.7, n.1, p.74-78, 2007.

RADMANN, E.B. et al. Efeito de auxinas e condiçóes de cultivo no enraizamento in vitro de porta-enxertos de macieira 'M-9'. Revista Brasileira de Fruticultura, Jaboticabal, v.24, n.3, 2002.

REIS, S. et al. Influência do meio de cultura na germinação de sementes in vitro e taxa de multiplicação de Melissa officinalis L. Revista Ceres, Viçosa, v.55, n.3, p.160-167, 2008.

REIS, L. et al. Estratificação in vitro de embriôes zigóticos de pessegueiro em diferentes meios de cultura e concentraçôes de sacarose. Revista Brasileira de Fruticultura, Jaboticabal, v.34, n. 3, p.653-660, 2012.

REZENDE, J.C. et al. Influência do meio de cultura e concentração de ágar no crescimento e desenvolvimento de plântulas de café oriundas da embriogênese somática direta. Scientia Agraria, Curitiba, v.9, n.1, p.21-26, 2008.

RIBEIRO, L.S. et al. Desenvolvimento in vitro de embriôes zigóticos de Coffea arabica. Ciência e Agrotecnologia, Lavras, v.27, n.1, p.1479-1483, 2003.

SIMONETTO, P.; GRELLMANN, E. Pereira: Porta-enxertos e algumas cultivares. Porto Alegre: IPAGRO, 1988.

SOARES FILHO, W.S. et al. Freqüência de híbridos em cruzamentos controlados de citros: cultivo de sementes versus cultivo in vitro de embrióes. Pesquisa Agropecuária Brasileira, v.37, n.7, 2002.

SOARES, J.D.R. et al. Germinação de embriôes e crescimento inicial in vitro de macaúba. Ciência Rural, Santa Maria, v.41, n.5, p.773-778, 2011.

TORRES, A.C.; CALDAS, L.S. Técnicas e aplicaçóes da cultura de tecidos de plantas. Brasília: EMBRAPA,1990. 